\title{
EL POTENCIAL DE LOS PAISAJES CULTURALES COMO FACTOR DE DESARROLLO REGIONAL SUSTENTABLE
}

\author{
Edgardo José Venturini \\ Instituto del Ambiente Humano-Facultad de Arquitectura, Urbanismo y Diseño \\ Universidad Nacional de Córdoba \\ edgardo.venturini@gmail.com
}

\section{RESUMEN}

El tema de la presentación está centrado en los paisajes culturales y su potencial de sustentabilidad y resiliencia en la construcción de un hábitat sustentable. Se parte del concepto amplio de paisaje cultural como resultado de la acción del trabajo humano sobre la naturaleza en los procesos de construcción social de lugares resultado de las prácticas del habitar, en los cuales se sintetizan múltiples y contradictorios procesos e intereses vinculados con las transformaciones del espacio geográfico ambiental. En este sentido, se asume el territorio como un campo híbrido por la complejidad y diversidad de cuestiones que se asocian con el concepto. Aquí se introduce el enfoque de paisaje cultural que, partiendo de una construcción epistemológica híbrida, asocia las condiciones geográfico-ambientales con las prácticas de los actores sociales y los resultados de sus complejas y contradictorias actuaciones en el medio, evidenciando siempre "la marca de una finalidad, incluso de varias, dado que la movilidad humana ha sido grande, las sustituciones numerosas y los medios técnicos variados".

El trabajo se desarrolla a partir de relevamientos bibliográficos y de antecedentes locales, nacionales e internacionales, y su discusión, estudios de campo, para luego avanzar sobre la formulación de nuevas estrategias conceptuales y metodológicas. El caso en análisis es el área metropolitana de Córdoba y el área del antiguo Camino Real al Norte en la Provincia de Córdoba. Palabras clave: paisaje cultural - sustentabilidad - ordenamiento territorial - hábitat sustentable - patrimonio

\section{ASTRACT}

The paper is centered on cultural landscapes and their potential for sustainability and resilience in the construction of a sustainable habitat. It starts from the broad concept of cultural landscape as a result of the action of human work on nature in the processes of social construction of places resulting from the practices of inhabiting, in which multiple and contradictory processes and interests linked to the transformations of the environment are synthesized in environmental geographic space. The territory is assumed as a hybrid field due to the complexity and diversity of issues that are associated with the concept. Here we introduce the cultural landscape approach that, starting from a hybrid epistemological construction, associates geographical-environmental conditions with the practices of social actors and the results of their complex and contradictory actions in the environment, always demonstrating "the brand of a purpose, even of several, given that human mobility has been great, numerous substitutions and varied technical means ".

The work is developed from bibliographic surveys and local, national and international background, and its discussion, field studies, to then advance on the formulation of new conceptual and methodological strategies. The case under analysis is the metropolitan area of Córdoba and the area of the old Camino Real to the North in the Province of Córdoba.

Key words: cultural landscape - sustainability - territorial organization - sustainable habitat heritage 